Prepared in cooperation with the Friends of the North Fork of the Shenandoah River

\title{
Investigation of Organic Chemicals Potentially Responsible for Mortality and Intersex in Fish of the North Fork of the Shenandoah River, Virginia, during Spring of 2007
}

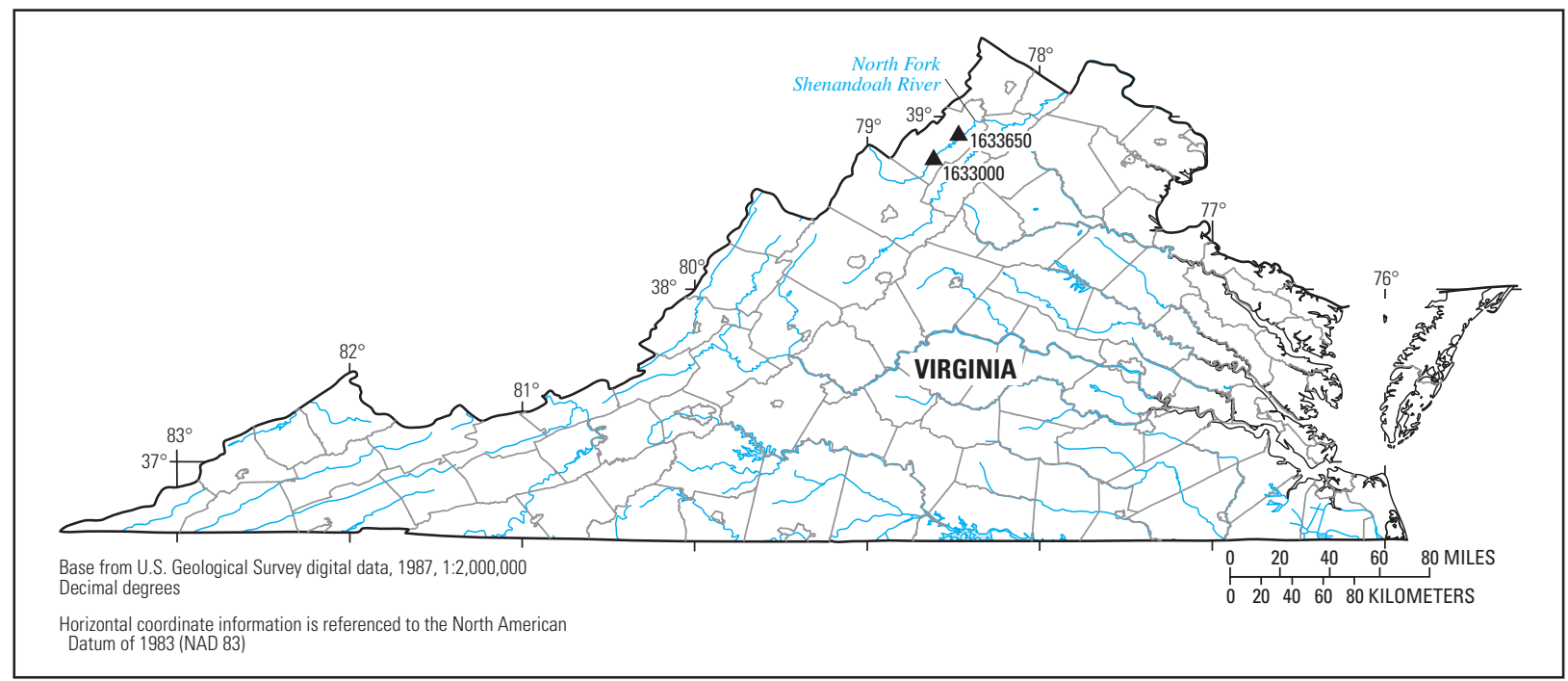

Open-File Report 2008-1093 
Cover. Map showing location of the two sampling sites on the North Fork of the Shenandoah River, Virginia. 


\section{Investigation of Organic Chemicals Potentially Responsible for Mortality and Intersex in Fish of the North Fork of the Shenandoah River, Virginia, during Spring of 2007}

By David A. Alvarez', Walter L. Cranor', Stephanie D. Perkins', Vickie L.

Schroeder ${ }^{2}$, Stephen L. Werner ${ }^{3}$, Edward T. Furlong ${ }^{3}$, and John Holmes ${ }^{4}$

${ }^{1}$ U.S. Geological Survey, Columbia Environmental Research Center

${ }^{2}$ U.S. Geological Survey, Arctic Slope Regional Corporation

${ }^{3}$ U.S. Geological Survey, National Water Quality Laboratory

${ }^{4}$ Friends of the North Fork of the Shenandoah River

Prepared in cooperation with the Friends of the North Fork of the Shenandoah River

Open-File Report 2008-1093 


\section{U.S. Department of the Interior DIRK KEMPTHORNE, Secretary}

\section{U.S. Geological Survey \\ Mark D. Myers, Director}

\section{U.S. Geological Survey, Reston, Virginia: 2008}

For product and ordering information:

World Wide Web: http://www.usgs.gov/pubprod

Telephone: 1-888-ASK-USGS

For more information on the USGS--the Federal source for science about the Earth, its natural and living resources, natural hazards, and the environment:

World Wide Web: http://www.usgs.gov

Telephone: 1-888-ASK-USGS

Any use of trade, product, or firm names is for descriptive purposes only and does not imply endorsement by the U.S. Government.

Although this report is in the public domain, permission must be secured from the individual copyright owners to reproduce any copyrighted materials contained within this report.

Suggested citation:

Alvarez, D.A., Cranor, W.L., Perkins, S.D., Schroeder, V.L., Werner, S.L., Furlong, E.T., and Holmes, J., 2008, Investigation of organic chemicals potentially responsible for mortality and intersex in fish of the North Fork of the Shenandoah River, Virginia, during spring of 2007: U.S. Geological Survey Open-File Report 2008-1093, 16 p. 


\section{Contents}

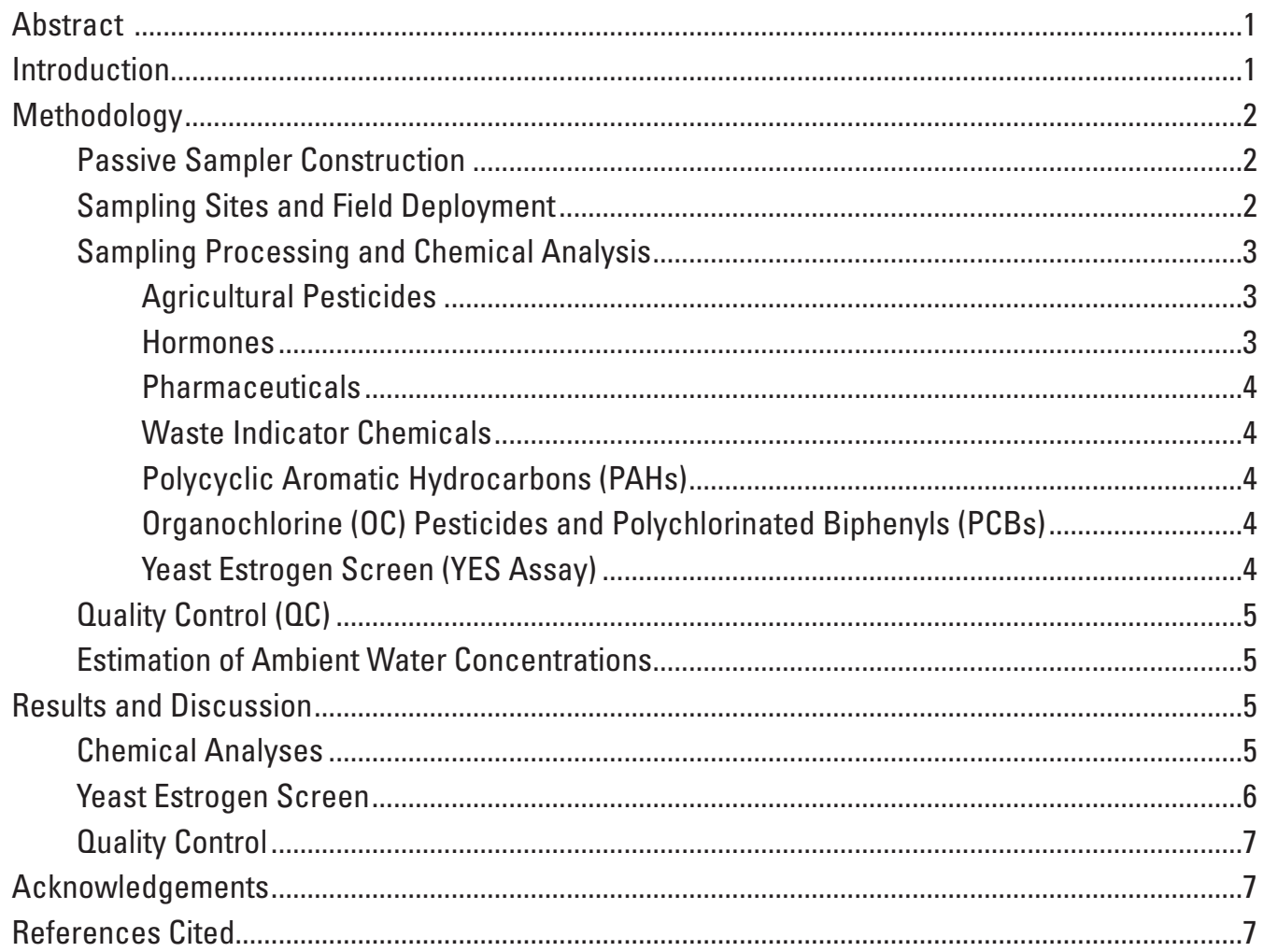

\section{Figure}

1. Map showing location of the two sampling sites on the North Fork of the Shenandoah River, Virginia.

\section{Tables}

1. Estimated water concentrations of select polycyclic aromatic hydrocarbons (PAHs) measured by semipermeable membrane devices (SPMDs) in the North Fork of the Shenandoah River, Virginia

2. Estimated water concentrations of select organochlorine pesticides and total polychlorinated biphenyls (PCBs) measured by semipermeable membrane devices (SPMDs) in the North Fork of the Shenandoah River, Virginia.

3. Estimated water concentrations and identification of select agricultural herbicides and pesticides measured by polar organic chemical integrative samplers (POCIS) in the North Fork of the Shenandoah River, Virginia

4. Identification of select waste-indicator chemicals measured by polar organic chemical integrative samplers (POCIS) in the North Fork of the Shenandoah River, Virginia 
5. Identification of select pharmaceuticals measured by polar organic chemical integrative samplers (POCIS) in the North Fork of the Shenandoah River, Virginia........15

6. Estimated water concentrations of select hormones measured by polar organic chemical integrative sampler (POCIS) in the North Fork of the Shenandoah River, Virginia.

7. Relative estrogenic potential of chemicals sampled by semipermeable membrane devices (SPMDs) and polar organic chemical integrative samplers (POCIS) deployed in the North Fork of the Shenandoah River, Virginia as determined by the Yeast Estrogen Screen (YES)

\section{Conversion Factors}

SI to Inch/Pound

\begin{tabular}{|c|c|c|}
\hline Multiply & By & To obtain \\
\hline \multicolumn{3}{|c|}{ Volume } \\
\hline liter $(\mathrm{L})$ & 33.82 & ounce, fluid (fl. oz) \\
\hline milliliter (mL) & 0.03382 & ounce, fluid (fl. oz) \\
\hline microliter $(\mu \mathrm{L})$ & $3.382 \times 10^{-5}$ & ounce, fluid (fl. oz) \\
\hline \multicolumn{3}{|c|}{ Length } \\
\hline meter $(\mathrm{m})$ & 3.281 & foot $(\mathrm{ft})$ \\
\hline centimeter $(\mathrm{cm})$ & 0.3937 & inch (in.) \\
\hline millimeter (mm) & 0.03937 & inch (in.) \\
\hline micrometer $(\mu \mathrm{m})$ & $3.937 \times 10^{-5}$ & inch (in.) \\
\hline \multicolumn{3}{|c|}{ Mass } \\
\hline $\operatorname{gram}(\mathrm{g})$ & 0.03527 & ounce, avoirdupois (oz) \\
\hline milligram (mg) & $3.527 \times 10^{-5}$ & ounce, avoirdupois (oz) \\
\hline microgram $(\mu \mathrm{g})$ & $3.527 \times 10^{-8}$ & ounce, avoirdupois (oz) \\
\hline nanogram (ng) & $3.527 \times 10^{-11}$ & ounce, avoirdupois (oz) \\
\hline \multicolumn{3}{|c|}{ Pressure } \\
\hline pound per square inch $\left(\mathrm{lb} / \mathrm{in}^{2}\right)$ & 6.895 & kilopascal (kPa) \\
\hline \multicolumn{3}{|c|}{ Concentration } \\
\hline nanogram per liter (ng/L) & $=$ & part per trillion $\left(\mathrm{ppt} ; 10^{12}\right)$ \\
\hline picogram per liter (pg/L) & $=$ & part per quadrillion $\left(\mathrm{ppb} ; 10^{15}\right.$ ) \\
\hline
\end{tabular}

Temperature in degrees Celsius $\left({ }^{\circ} \mathrm{C}\right)$ may be converted to degrees Fahrenheit $\left({ }^{\circ} \mathrm{F}\right)$ as follows:

${ }^{\circ} \mathrm{F}=\left(1.8 \mathrm{x}^{\circ} \mathrm{C}\right)+32$

Concentrations of chemical constituents in passive samplers are given in nanogram per sampler (ng/SPMD or ng/POCIS). Estimated water concentrations of chemical constituents are given in nanogram per liter ( $\mathrm{ng} / \mathrm{L})$ or picogram per liter $(\mathrm{pg} / \mathrm{L})$. 


\title{
Investigation of Organic Chemicals Potentially Responsible for Mortality and Intersex in Fish of the North Fork of the Shenandoah River, Virginia, during Spring of 2007
}

\author{
By David A. Alvarez', Walter L. Cranor' ${ }^{1}$ Stephanie D. Perkins', Vickie L. Schroeder ${ }^{2}$, Stephen L. Werner ${ }^{3}$, \\ Edward T. Furlong ${ }^{3}$, and John Holmes ${ }^{4}$
}

\section{Abstract}

Declining fish health, fish exhibiting external lesions, incidences of intersex, and death, have been observed recently within the Potomac River basin. The basin receives surface runoff and direct inputs from agricultural, industrial, and other human activities. Two locations on the North Fork of the Shenandoah River were selected for study in an attempt to identify chemicals that may have contributed to the declining fish health. Two passive sampling devices, semipermeable membrane devices (SPMDs) and polar organic chemical integrative samplers (POCIS), were deployed during consecutive two-month periods during the spring and early summer of 2007 to measure select organic contaminants to which fish may have been exposed. This study determined that concentrations of persistent hydrophobic contaminants, such as polycyclic aromatic hydrocarbons ( $<760$ picograms per liter), legacy pesticides ( $<10$ picograms per liter), and polychlorinated biphenyls ( $<280$ picograms per liter) were low and indicative of a largely agricultural area. Atrazine and simazine were the most commonly detected pesticides. Atrazine concentrations ranged from 68 to 170 nanograms per liter for the March to April study period and 320 to 650 nanograms per liter for the April to June study period. Few chemicals characteristic of wastewater treatment plant effluent or septic tank discharges were identified. In contrast, para-cresol, $N, N$-diethyltoluamide, and caffeine commonly were detected. Prescription pharmaceuticals including carbamazepine, venlafaxine, and

${ }^{1}$ U.S. Geological Survey, Columbia Environmental Research Center, 4200 New Haven Road, Columbia, Missouri 65201.

${ }^{2}$ U.S. Geological Survey, Arctic Slope Regional Corporation (ASRC), 4200 New Haven Road, Columbia, Missouri 65201.

${ }^{3}$ U.S. Geological Survey, National Water Quality Laboratory, Denver, Colorado 80225 .

${ }^{4}$ Friends of the North Fork of the Shenandoah River, P.O. Box 746, Woodstock, Virginia 22664.
$17 \alpha$-ethynylestradiol were at low concentrations. Extracts from the passive samplers also were screened for the presence of estrogenic chemicals using the yeast estrogen screen. An estrogenic response was observed in POCIS samples from both sites, whereas SPMD samples exhibited little to no estrogenicity. This indicates that the chemicals producing the estrogenic response have a greater water solubility and are, therefore, less likely to bioaccumulate in fatty tissues of organisms.

\section{Introduction}

Water-quality degradation poses an urgent threat to freshwater supplies and aquatic biodiversity. Fish kills and observations of intersex in fish have been increasing in regularity in the Shenandoah River and Potomac River basins in Virginia (Blazer and others, 2007). The fish kills and observations of intersex primarily have occurred during the spring, and mostly in smallmouth bass (Micropterus dolomieu), red-breast sunfish (Lepomis auritus), and various species of suckers. The cause(s) of these phenomena are unknown; however, the input of anthropogenic organic chemicals (AOCs) into the basin may be a factor. The U.S. Geological Survey in cooperation with the Friends of the North Fork of the Shenandoah River (FNFSR), a non-profit organization, conducted this study to identify AOCs in the river water and assess the estrogenicity of the complex mixtures of chemicals present using an in vitro assay.

Passive sampling technology was chosen to characterize AOCs in the watershed because of the expected low concentrations, and to measure only those chemicals that were available for uptake into fish. Passive samplers are deployed for weeks to months and extract chemicals continously from the water. Passive samplers sample only dissolved chemicals, excluding those associated with particulate, suspended sediment, or colloidal matter. During a typical one-month exposure, a passive 
sampler potentially can sample tens to hundreds of liters (L) of water, detecting chemicals present at low concentrations, or those that are present episodically. This time integration of contaminant presence is not readily achievable using standard sampling methods that collect discrete 1- or 2-L water samples. Results from the analysis of the passive sampler data provide a time-weighted average concentration of chemicals that are a fundamental part of risk assessment determinations.

Semipermeable membrane devices (SPMDs) are widely used passive samplers that consist of a layflat polyethylene membrane tube that contains a high purity neutral lipid (triolein) and are designed to mimic key aspects of contaminant bioconcentration, resulting in elevated contaminant concentrations in organism tissues after exposure to trace hydrophobic AOCs in aquatic environments (Huckins and others, 2006). Sampling of organic compounds with moderate to high octanol-water partition coefficients $\left(K_{\text {ow }}\right.$ s) generally is integrative (extracted chemicals constantly are accumulated without significant losses back into the environment).

Similarly, the polar organic chemical integrative sampler (POCIS) was designed to mimic key aspects of the bioconcentration process, via respiration, and an organism's exposure to hydrophilic AOCs (Alvarez and others, 2004). The POCIS consists of a solid phase sorbent or mixture of sorbents contained between two sheets of a microporous polyethersulfone membrane. Sampling AOCs with low to moderate $K_{\text {ow }}$ s (log $K_{\text {ow }}<3$ ) is integrative, and analyte concentrations are reported as time weighted average values. Water concentrations may be estimated if the uptake kinetics (sampling rates) for the targeted chemical(s) are known (Alvarez and others, 2007). The POCIS has previously been used to monitor for trace concentrations of pharmaceuticals, pesticides, hormones, and wastewater-related chemicals (Alvarez and others, 2004; 2005; 2007; in press; Jones-Lepp and others, 2004; Petty and others, 2004).

In this work, passive samplers were used to determine the presence of potentially endocrine-disrupting compounds and other chemicals at two locations on the North Fork of the Shenandoah River. SPMDs and POCIS were deployed during two successive 6-week periods in the spring of 2007 to address the potential impact of agricultural and municipal inputs into the basin during the time of year when fish kills have been most prevalent. A suite of AOCs was selected for study, including polycyclic aromatic hydrocarbons (PAHs), legacy organochlorine pesticides (OCs), polychlorinated biphenyls (total PCBs), select natural and synthetic hormones, currentuse agricultural pesticides, pharmaceuticals, and select waste indicator contaminants.

\section{Methodology}

\section{Passive Sampler Construction}

The POCIS used in this study contained Oasis HLB as the chemical sequestration medium enclosed between two polyethersulfone membranes. Oasis HLB is a functionalized polystyrene-divinylbenzene polymer with blended hydrophilic-lipophilic properties, commonly used in environmental monitoring studies for a wide range of organic contaminants. Each POCIS unit had an effective sampling surface area of 41 square centimeters $\left(\mathrm{cm}^{2}\right)$ and a membrane surface area to sorbent mass ratio of 180 square centimeters per gram $\left(\mathrm{cm}^{2} / \mathrm{g}\right)$ conforming to the specification of a standard POCIS (Alvarez and others, 2004). Each of the protective field deployment canisters contained six POCIS units. Field blanks, each containing three POCIS, were used at each site.

The SPMDs consisted of 97 centimeters $(\mathrm{cm})$ long $(86$ $\mathrm{cm}$ between the lipid-containment seals) by $2.5 \mathrm{~cm}$ wide layflat low-density polyethylene tubing containing 1.0 milliliter (mL) of purified triolein (Lebo and others, 2004). The membrane surface area to total SPMD volume ratio of SPMDs used in this study was 86 square centimeters per $\mathrm{mL}\left(\mathrm{cm}^{2} / \mathrm{mL}\right)$, and triolein represented 20 percent of the mass of the SPMDs conforming to a "standard SPMD" as defined by Huckins and others (2006). Two of the four SPMDs in each deployment canister and two of the four field blank SPMDs at each site were fortified with 1 microgram $(\mu \mathrm{g})$ of each of the five perdeuterated polycyclic aromatic hydrocarbons (PAHs) selected as performance reference compounds (PRCs-acenaphthylene- $d_{10}$, acenaphthene- $d_{10}$, fluorene- $d_{10}$, phenanthrene- $d_{10}$ and pyrene- $\left.d_{10}\right)$. A description of the PRC approach is given in the Estimation of Ambient Water Concentrations section.

\section{Sampling Sites and Field Deployment}

Two sites were selected on the North Fork of the Shenandoah River (fig. 1). The first was near the town of Woodstock, Virginia, at Pugh's Run (USGS streamflow-gaging station number 1633650) and the second was near the town of Mount Jackson, Virginia, near Red Banks (USGS streamflow-gaging station number 1633000). During the first and second deployments, diseased and dead fish were present at the Woodstock site. No reports of fish were made at the Mount Jackson site at the time of sampling. At each site, two protective deployment canisters containing SPMDs and POCIS were deployed for two successive periods of 42-50 days between March and June, 2007. After retrieval from the field, the samplers were sealed in airtight shipping containers, placed in coolers on blue ice, and returned to the laboratory where they were inspected and stored at less than -20 degress Celsius $\left({ }^{\circ} \mathrm{C}\right)$ until processing and analysis. 


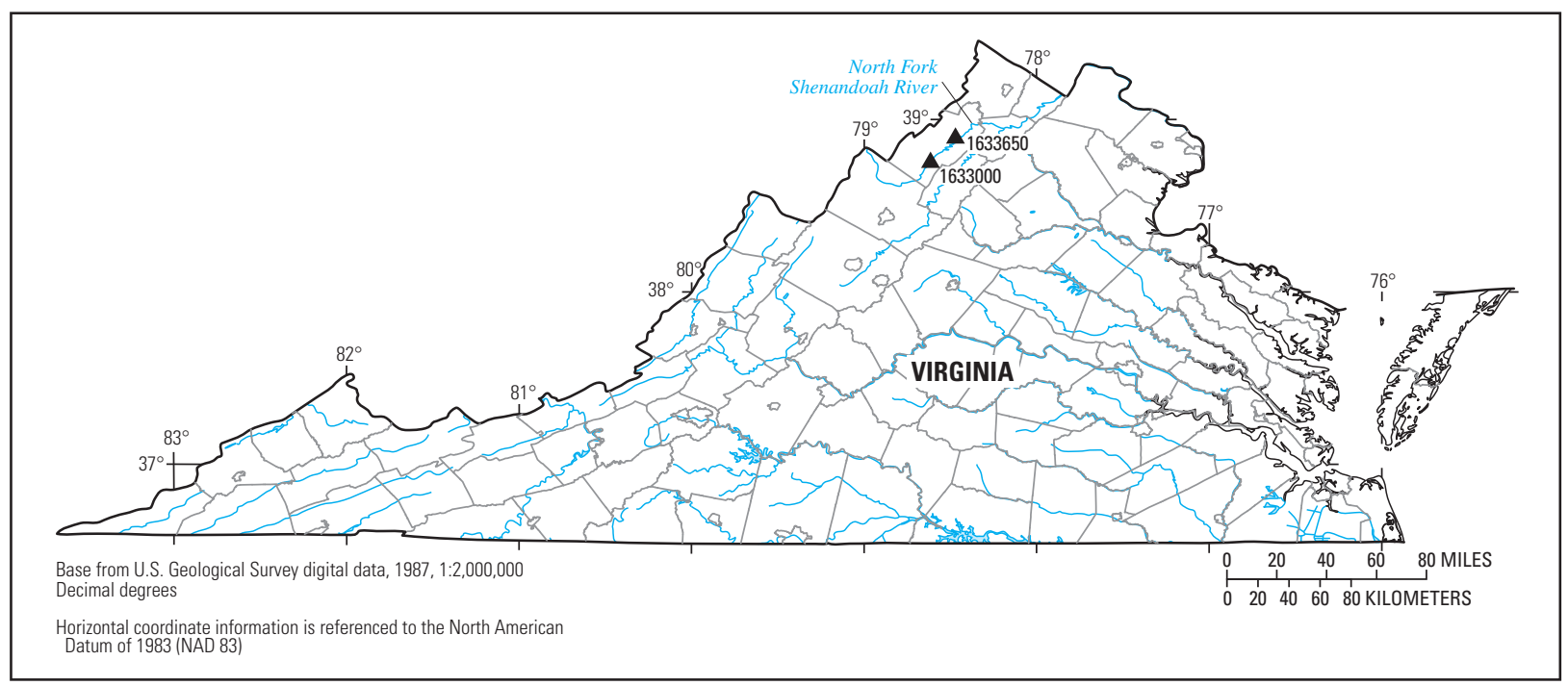

Figure 1. Location of the two sampling sites on the North Fork of the Shenandoah River. The Woodstock, Virginia, at Pugh's Run site was located at USGS streamflow-gaging station 1633650 and the Mount Jackson, Virginia, near Red Rocks site was located at USGS streamflow-gaging station 1633000.

\section{Sampling Processing and Chemical Analysis}

Each POCIS and SPMD was extracted individually before designating extracts for specific processing and analysis procedures. Agricultural pesticides, hormones, pharmaceuticals, and select waste indicator contaminants were measured in the POCIS. SPMDs were processed and analyzed for PAHs, OC pesticides, and total PCBs. Both POCIS and SPMD extracts were screened using the yeast estrogen screen (YES assay) to test for the total estrogenicity of sampled chemicals (Alvarez and others, in press; Rastall and others, 2004).

Published procedures were used for preparing the POCIS samples for analysis in this study (Alvarez and others, 2004, 2007, in press). Chemicals of interest were recovered from the POCIS sorbent using $40 \mathrm{~mL}$ of methanol, with the exception of two POCIS from each deployment canister that were designated for waste indicator chemical analysis. These two POCIS were extracted using $25 \mathrm{~mL}$ of a 80:20 volume-to-volume ratio (v:v) dichloromethane:methyl-tert-butyl ether solution. The liquid volume of each extract was reduced by rotary evaporation and filtered through 0.45 micrometer $(\mu \mathrm{m})$ filter cartridges. From each deployment canister, the extracts from the two waste indicator POCIS were composited into a 2-POCIS equivalent sample, thereby increasing the amount of chemical present in each sample to aid in detection. The remaining four POCIS extracts from each deployment canister were kept as individual samples designated for processing for agricultural pesticides, hormones, pharmaceuticals, and the YES assay.

The procedures used for preparing SPMD samples for analysis were similar to previously published approaches (Alvarez and others, in press; Petty and others, 2000). Briefly, the target analytes were recovered from the SPMDs by dialysis with hexane, followed by class-specific cleanup and analysis.
One of the PRC-SPMDs from each deployment canister was used for the analysis of PAHs; the other was used for OC pesticide and total PCB measurements. One of the SPMDs not containing PRCs in each canister was screened for estrogenic chemicals by the YES assay and the remaining SPMD was held in reserve.

\section{Agricultural Pesticides}

Details for the processing and analysis of POCIS for agricultural pesticides have been reported previously (Alvarez and others, in press). Briefly, the extracts were fractionated using size exclusion chromatography (SEC), followed by sample cleanup and enrichment by Florisil adsorption chromatography. Analysis was performed using an Agilent 6890 gas chromatograph (GC, Agilent Technologies, Inc., Wilmington, Delaware) coupled to a 5973N mass selective detector (MSD, Agilent Technologies, Inc., Palo Alto, California) with a HP5MS $[30$ meter $(\mathrm{m})$ x 0.25 millimeter $(\mathrm{mm})$ inner diameter $\mathrm{x}$ $0.25 \mu \mathrm{m}$ film thickness) capillary column (Agilent Technologies, Inc., Wilmington, Delaware). Instrumental parameters have been described by Alvarez and others (in press).

\section{Hormones}

Four common natural and synthetic hormones were targeted in this study. Extracts selected for hormone analysis required derivatization of the hormones to facilitate their analysis by a gas chromatograph with a mass selective detector (GC/MSD). Derivatization of extracts, quality control (QC) samples, and calibration standards for GC/MSD analysis were initiated by evaporating the samples to dryness under purified nitrogen, followed by the addition of 200 microliters $(\mu \mathrm{L})$ of 
dichloromethane and $200 \mu \mathrm{L}$ of 2 percent methoxyamine$\mathrm{HCl}$ in pyridine. The samples were sealed in capped tubes and heated at $70^{\circ} \mathrm{C}$ for 2 hours. Then, a mixture of $175 \mu \mathrm{L}$ of Bis(trimethylsilyl)trifluoroacetamide (BSTFA) $+1 \%$ trimethylchlorosilane (TMCS) and $100 \mu \mathrm{L}$ of triethylamine was added to the samples, and returned to the heating block at $70{ }^{\circ} \mathrm{C}$ for an additional 18 hours. The derivatized samples were then solvent exchanged into hexane, and processed through columns containing 300 milligrams (mg) of silica gel to remove color and any precipitate. A total of $10 \mathrm{~mL}$ of hexane was used to transfer the samples to the silica gel columns and to recover the derivatized hormones. Analysis of the derivatized extracts was performed using the GC/MSD system previously described with a temperature program of injection at $90{ }^{\circ} \mathrm{C}$, ramped at $25{ }^{\circ} \mathrm{C}$ per minute (min) to $200{ }^{\circ} \mathrm{C}$, then $4{ }^{\circ} \mathrm{C} / \mathrm{min}$ ramp to $255^{\circ} \mathrm{C}$, ramped at $10^{\circ} \mathrm{C} / \mathrm{min}$ to $310^{\circ} \mathrm{C}$ and held at $310^{\circ} \mathrm{C}$ for 3 minutes.

\section{Pharmaceuticals}

Extracts for pharmaceutical analysis were solvent exchanged into acetonitrile and sealed in amber glass ampoules before being shipped to the USGS National Water Quality Laboratory in Denver, Colorado, for analysis using liquid chromatography/tandem mass spectrometry (LC/MS/ MS). Each sample extract was analyzed first on a liquid chromatography/mass spectrometer (LC/MS/MS) system (Series 1100 LC; Agilent, Palo Alto, California, \& Q-Trap Mass Spectrometer; Applied Biosystems, Foster City, California) with electrospray ionization in the positive mode using multiplereaction monitoring (MRM) mode, to confirm the identity of pharmaceuticals. Two analyses of the POCIS extracts were performed; one for a suite of commonly used prescription and over-the-counter pharmaceuticals, and a second for current-use antidepressants. Chromatographic separation of the commonly used pharmaceuticals was performed using a binary water/acetonitrile gradient and a $\mathrm{C}_{18}$ reversed phase $\mathrm{LC}$ column (Zorbax SB-C18 Rapid Resolution 2.1 x 30 mm 1.8 $\mu \mathrm{m}$, Agilent Techonolgies, Santa Clara, California). The LC instrument parameters used in this study were modified from Cahill and others (2004). The LC was interfaced directly to the electrospray ionization (ESI) source coupled to an Applied Biosystems/MDS Sciex 2000 QTrap (Framingham, Massachusetts). The QTrap is a hybrid triple quadrupole/linear ion trap mass spectrometer that has MS/MS and MS/MS/MS capabilities. The QTrap ion source was operated in positive ESI mode, and MRM transition mode was used for sample analysis. For the common-use pharmaceuticals, two MRM transitions, one a quantitation product ion, and one a confirmation product ion were acquired for each analyte. Optimal instrumental source parameters are as follows: ion spray voltage $-4,000$ volts (V); nebulizer gas pressure-40 pounds per square inch gauge (psig); heater gas pressure-40 psig; collision gas pressure-6 psig; auxiliary source gas pressure-40psig; and source temperature- $450{ }^{\circ} \mathrm{C}$. The declustering potentials and collision energies were analyte dependent, but ranged from 10 to $60 \mathrm{~V}$ and 7 to 50 electron volts $(\mathrm{eV})$, respectively. The current-use antidepressants were determined using the LC/MS/MS instrumental analysis of Schultz and Furlong (2008).

\section{Waste Indicator Chemicals}

Analysis of waste indicator chemicals was performed on raw POCIS extracts because of the difficulty in adequately "cleaning-up" a sample while maintaining the integrity of such a diverse set of chemicals. Analyses were performed on the GC/MSD system previously described using a temperature program of injection at $40^{\circ} \mathrm{C}$, held for 3 minutes, then ramped at $9{ }^{\circ} \mathrm{C} / \mathrm{min}$ to $320^{\circ} \mathrm{C}$ and held at $320^{\circ} \mathrm{C}$ for 3 minutes. Identification of the targeted chemicals was performed using full-scan MS, and quantification was performed by selecting ions unique to each chemical.

\section{Polycyclic Aromatic Hydrocarbons (PAHs)}

Following SEC, samples designated for PRCs and PAHs were processed using a tri-adsorbent column consisting of phosphoric acid silica gel, potassium hydroxide impregnated silica gel, and silica gel (Petty and others, 2000). The GC analyses for selected PAHs and PRCs were conducted using the GC/MSD system previously described with the instrumental conditions as reported by Alvarez and others (in press).

\section{Organochlorine (OC) Pesticides and Polychlorinated Biphenyls (PCBs)}

The OC/PCB SPMD samples were further enriched after SEC using a Florisil column followed by fractionation on silica gel (Petty and others, 2000). The first silica gel fraction (SG1) contained greater than 95 percent of the total PCBs, hexachlorobenzene, heptachlor, mirex and 40 to 80 percent of the $p, p$ '-DDE when present in extracts. The second fraction (SG2) contained the remaining 28 target OC pesticides and less than 5 percent of the total PCBs (largely, mono- and dichlorobiphenyl congeners). Analysis of the SPMD samples for PCBs and OCs were conducted using a Hewlett Packard 5890 series GC equipped with an electron capture detector (ECD, Hewlett Packard, Inc., Palo Alto, California) and a DB35MS (30 m x $0.25 \mathrm{~mm}$ i.d. x $0.25 \mu \mathrm{m}$ film thickness) capillary column (J\&W Scientific, Folsom, California). Instrumental conditions for the OC/PCB analyses have been previously reported (Alvarez and others, in press).

\section{Yeast Estrogen Screen (YES Assay)}

The YES assay uses recombinant yeast cells transfected with the human estrogen receptor. Upon binding these cells to an estrogen or estrogen-mimic, a cascade of biochemical reactions occurs resulting in a color change that can be measured spectrophotometrically (Routledge and Sumpter, 1996; 
Rastall and others, 2004). SPMDs and POCIS extracts from each site were screened for total estrogenicity in conjunction with a series of negative (solvent) and positive (17 $\beta$-estradiol) controls (Alvarez and others, in press; Rastall and others, 2004). Estradiol equivalent factors (EEQ) for the samples were calculated to provide a relative measure of estrogenicity. The EEQ is an estimate of the amount of $17 \beta$-estradiol, a natural hormone, that would be required to give a response equivalent to that of the complex mixture of chemicals sampled at each site.

\section{Quality Control (OC)}

A rigorous QC plan was employed to ensure the reliability of the data obtained. The QC samples for the SPMDs and POCIS consisted of fabrication and field blanks intended to determine the presence of any contamination of the sampler matrix during construction in the laboratory and handling in the field. Laboratory controls such as reagent blanks, matrix blanks, surrogate recovery, and fortified matrix recovery checks were included in the construction, deployment, and processing of the study samples. Instrument verification checks, reference standards, and positive and negative controls for the YES assay were employed throughout the study. Detailed discussions on the benefits of each type of control sample have been reported in Alvarez and others (2007) and Huckins and others (2006).

Method detection (MDL) and quantification (MQL) limits were estimated from low-level calibration standards as determined by the signal-to-noise ratio of the response from the instrumental analysis (Keith, 1991). The MDLs were determined as the mean plus three standard deviations of the response of a coincident peak present during instrumental analysis. The MQLs were determined as the greater of either the coincident peak mean plus 10 standard deviations, or the concentration of the lowest-level calibration standard. In cases where no coincident peak was present, the MQL was set at the lowest-level calibration standard and the MDL was estimated to be 20 percent of the MQL.

\section{Estimation of Ambient Water Concentrations}

SPMD and POCIS uptake kinetics (sampling rates) are required to estimate aquatic concentrations of environmental contaminants. Using previously developed models (Alvarez and others, 2004, 2007; Huckins and others, 2006) along with data from the analysis of the PRC concentrations and sampling rates (when available), the bioavailable concentrations of analytes in POCIS and SPMDs can be estimated.

The effects of exposure conditions on the chemical uptake and dissipation rates into passive samplers are largely a function of exposure medium temperature; facial velocity/ turbulence at the membrane surface, which in turn is affected by the design of the deployment apparatus (baffling of media flow-turbulence); and membrane biofouling. PRCs analyti- cally are non-interfering organic compounds with moderate to high fugacity from SPMDs that are added to the lipid before membrane enclosure and field deployment (Huckins and others, 2006). By comparing the rate of PRC loss during field exposures to that of laboratory studies, an exposure adjustment factor (EAF) can be derived and used to adjust sampling rates to more accurately reflect the site-specific sampling rates. A mixture of PRCs often is used to ensure at least one will have the optimal 20-80 percent loss (Huckins and others, 2006). PRCs will undergo increased loss as their $\log K_{\text {ow }}$ value decreases. The amount of loss will be dependant on the same environmental factors which affect chemical uptake. Because of the strong sorptive properties of the adsorbents used in the POCIS, attempts to incorporate PRCs into the POCIS have failed (Alvarez and others, 2007).

Uptake of hydrophobic chemicals into SPMDs follows linear, curvilinear, and equilibrium phases of sampling. Integrative (or linear) sampling is the predominant phase for compounds with $\log K_{\mathrm{ow}}$ values $\geq 5.0$ and exposure periods of up to one month. During the linear uptake phase the ambient chemical concentration $\left(C_{\mathrm{w}}\right)$ is determined by

$$
C_{\mathrm{w}}=N / R_{\mathrm{s}} \mathrm{t}
$$

where $\quad N \quad$ is the amount of the chemical sampled by an SPMD (typically ng),

$$
\begin{aligned}
R_{\mathrm{s}} & \text { is the SPMD sampling rate }(\mathrm{L} / \mathrm{d}), \text { and } \\
\mathrm{t} & \text { is the exposure time }(\mathrm{d}) .
\end{aligned}
$$

Estimation of a chemical's site specific $R_{\mathrm{s}}$ in an SPMD is the calculated EAF from the PRC data multiplied by the $R_{\mathrm{s}}$ measured during laboratory calibration studies (Huckins and others, 2006). A key feature of the EAF is that it is relatively constant for all chemicals that have the same rate-limiting barrier to uptake, allowing PRC data to be applied to a range of chemicals.

Uptake of hydrophilic organic chemicals by the POCIS is controlled by many of the same rate-limiting barriers allowing the use of the same models to determine ambient water concentrations. Previous data indicate that many chemicals of interest remain in the linear phase of sampling for at least 56 days (Alvarez and others, 2004, 2007); therefore, the use of a linear uptake model (eq. 1) for the calculation of ambient water concentrations was justified.

\section{Results and Discussion}

\section{Chemical Analyses}

The data presented in tables 1-6 (at the back of this report) are reported as estimated water concentrations, when possible. In cases where the sampling rate for a chemical was not known, the data were flagged as not calculated (NC), and the result was given as mass of chemical in the passive 
sampler. Although the mass of chemical per sampler data is more qualitative, it is still useful in identifying chemicals present at a site and comparing the relative amounts of a chemical between sites. Data that were less than the MDL were given as a " $<$ " value based on the estimated water concentration of the detection limit under those site conditions (deployment time, flow, temperature, and biofouling) or as the mass of chemical per sampler. Data that are greater than the MDL, but less than the MQL, are shown in italics. Any data less than the MQL have a large degree of statistical uncertainty and are presented for informational purposes only. All reportable data greater than the MQL are shown in bold type.

PAHs (table 1) identified in the study generally were at low concentrations indicative of a rural setting with minimal urbanization or industrial impact. The primary PAHs present included fluoranthene, pyrene, phenanthrene, and the substituted naphthalenes commonly measured in environmental samples. Phenanthrene had the largest concentration of the identified PAHs of 760 picograms per liter (pg/L) from the first deployment at the Woodstock site. Few OC pesticides were present at reportable concentrations $>\mathrm{MQL}$ (table 2). The persistent legacy pesticides such as cis- and trans-chlordane, trans-nonachlor, and DDE were present at low concentrations ranging from 1.8 to $10 \mathrm{pg} / \mathrm{L}$. The presence of these pesticides is not surprising because of their nearly ubiquitous global distribution from years of excessive use before being banned. PCBs were not detected at concentrations greater than the MQL at any site or deployment (table 2). The triazine herbicides, atrazine, and simazine were the most commonly detected agricultural pesticides with reportable concentrations at all sites and deployments. Atrazine concentrations ranged from 68 to 170 nanograms per liter (ng/L) in deployment 1 and from 320 to $650 \mathrm{ng} / \mathrm{L}$ during deployment 2 . The atrazine metabolite desethylatrazine also was detected at all sites (table 3). Carbaryl, marketed under the trade name Sevin, was identified, albeit at concentrations near the MQL, in POCIS from both sites during the second deployment.

Few waste indicator chemicals were identified indicating minimal impact because of effluents from wastewater treatment plants (WWTPs) or leaking septic systems (table 4). The lack of fragrance chemicals, especially galaxolide and tonalide, further suggest the sites have little impact from WWTPs. Para-cresol, a component of the wood preservative creosote commonly used on telephone poles, railroad ties, and timber, was identified at all sites. The mosquito repellant, $\mathrm{N}, \mathrm{N}$-diethyltoluamide (DEET), also was identified at all sites. Since DEET was not present in the field blanks, contamination by field personnel was not suspected. It is possible that DEET concentrations in the river may be because of recreational use of the river (fishing). Caffeine, a common marker of wastewater effluent, was detected in some samples, but near the MDL using the GC/MSD instrumental method. The presence of caffeine in the samples was confirmed by the pharmaceutical scan using LC/MS as the instrumental method (table 5). As observed for the waste indicator chemicals, few pharmaceuticals were identified in the POCIS extracts (table
5). Carbamazepine, an anticonvulsant drug, was measured at a concentration near the MDL in one replicate from the second deployment at the Woodstock site. Codeine, a narcotic analgesic, also was detected in a single replicate from the second deployment at the Mount Jackson site. The antidepressant Venlafaxine, currently the thirteenth most prescribed drug in the United States and sold under the trade name Effexor (RxList, 2008), was identified at both sites during each deployment. The observed amounts of venlafaxine in the POCIS extracts (1.2-10 ng/POCIS) are much lower than levels present in WWTP effluent dominated stream samples (600-1,000 ng/L) reported by Schultz and Furlong (2008). Four steroidal hormones were targeted in this work (table 6) including the natural hormone $17 \beta$-estradiol, the synthetic hormone $17 \alpha$-ethynylestradiol (the main ingredient in oral contraceptives), and the $17 \beta$-estradiol metabolites, estriol and estrone. $17 \alpha$-ethynylestradiol was the only hormone detected and its concentrations were below the MQL (table 6).

Comparison of the data from the first and second deployments revealed no substantial differences between the occurrence or concentrations of $\mathrm{OC}$ pesticides, PAHs, waste indicator chemicals, or pharmaceuticals. Chlorpyrifos was a notable exception, as its water concentration at the Mount Jackson sampling site in the second deployment was approximately twice the concentration observed in the first deployment. The greatest differences were in the concentrations of the agricultural pesticides atrazine and simazine. For both chemicals, the concentrations were three to five-fold greater in the second deployment and likely were related to increased pesticide application during the spring crop planting in the largely agricultural reaches of the watershed. Desethylatrazine, an atrazine degradation product, also was measured in all samples with an approximate two-fold increase in the second deployment.

\section{Yeast Estrogen Screen}

There was measurable estrogenicity in each of the site samples (table 7, at the back of this report). No estrogenic response was observed from the blanks, indicating that the sampler matrix and sample processing steps did not contribute to the total measured estrogenicity. At each site, two POCIS were screened for estrogenicity. The precision between the replicate estimated EEQ values at select sites was greater than expected, and may have been because of positioning with respect to flow in the sites (greater flow results in more chemical sampled and potentially a higher EEQ) and/or one sampler becoming partially covered with sediment reducing the amount of chemicals sampled.

The EEQ observed in the SPMD samples was close to background levels, whereas the POCIS estimates were much greater. This indicates that the chemical(s) responsible for promoting the estrogenic response are more water soluble (polar) and less likely to bioaccumulate in fish and other aquatic organisms. Nevertheless, polar chemicals are suspected to have adverse effects on aquatic organisms, even though they 
may not bioaccumulate, because of their constant input into the basin (Daughton and Ternes, 1999). Of the chemicals identified, para-cresol is a known estrogen-mimic (Nishihara and others, 2000). In addition to para-cresol, some of the observed estrogenicity also may have resulted from the measured $17 \alpha$-ethynylestradiol in the second deployment. Routledge and others (1998) suggested that $17 \alpha$-ethynylestradiol could produce an estrogenic response at concentrations 10-fold lower than other natural steroids. Denny and others (2005) indicated that $17 \alpha$-ethynylestradiol has a higher affinity for the fish estrogen receptor than natural estrogens and presumably a greater biological potency. It is not known if the trace levels of para-cresol and $17 \alpha$-ethynylestradiol are the sole causes of the estrogenic response in these samples because of the large numbers of natural and synthetic polar chemicals that are known to be estrogen-mimicking compounds, and were not part of the targeted chemical list. Using a toxicity identification and evaluation (TIE) process, whereby a sample is split into several fractions that are individually analyzed, would be required to better assess the extent of estrogenic chemicals present in the passive sampler extracts.

\section{Quality Control}

Throughout the passive sampler processing and procedural steps, matrix spikes and instrumental verification checks were employed to monitor analyte recovery and chemical background contamination. Radiolabeled surrogates of model compounds were used to allow for a rapid determination of results. A freshly prepared SPMD was fortified with ${ }^{14} \mathrm{C}$ phenanthrene (a common PAH) and processed concurrently with the remainder of the study SPMDs. The measured recovery of the ${ }^{14} \mathrm{C}$ phenanthrene of 92 percent indicated acceptable performance of the dialysis and SEC processing steps. Select POCIS were spiked with ${ }^{3} \mathrm{H} 17 \alpha$-ethynylestradiol (a widely used synthetic hormone) and ${ }^{14} \mathrm{C}$ diazinon (a common organophosphate insecticide) resulting in mean recoveries of 95 percent (4.4 percent relative standard deviation) and 84 percent (4.5 percent relative standard deviation) from triplicate measurements. Recovery of chemicals processed by the SEC system, monitored using ${ }^{14} \mathrm{C}$ phenanthrene, averaged 97 percent with 1.7 percent relative standard deviation $(n=4)$.

Matrix (fabrication and field) blanks for the passive samplers were processed and analyzed concurrently with the field deployed samplers. Overall, the blanks indicated no sample contamination because of the materials and/or processing and handling of the samplers in the laboratory or field. For reporting purposes, the MDLs and MQLs for each sample set were calculated as ambient water concentrations based on the average PRC data across the sites for each sampling period. When sampling rate information was not available, the MDLs and MQLs were expressed as the mass of chemical sequestered by a single sampler (ng/POCIS or ng/SPMD).

\section{Acknowledgements}

The authors graciously thank the Friends of the North Fork of the Shenandoah River organization and their supporters, including the Virginia Environmental Endowment, for providing funding for this work. We also thank John Holmes and his colleagues at the Friends of the North Fork of the Shenandoah River for their efforts in the deployment and retrieval of the passive samplers.

\section{References Cited}

Alvarez, D.A., Petty, J.D., Huckins, J.N, Jones-Lepp, T.L., Getting, D.T., Goddard, J.P., Manahan, S.E., 2004, Development of a passive, in situ, integrative sampler for hydrophilic organic contaminants in aquatic environments: Environmental Toxicology Chemistry, v. 23, p. 1,640-1,648.

Alvarez, D.A., Stackelberg, P.E., Petty, J.D., Huckins, J.N., Furlong, E.T., Zaugg, S.D., Meyer, M.T., 2005, Comparison of a novel passive sampler to standard water-column sampling for organic contaminants associated with wastewater effluents entering a New Jersey stream: Chemosphere, v. 61, p. 610-622.

Alvarez, D.A., Huckins, J.N., Petty, J.D., Jones-Lepp, T.L., Stuer-Lauridsen, F., Getting, D.T., Goddard, J.P., Gravell, A., 2007, Tool for monitoring hydrophilic contaminants in water: polar organic chemical integrative sampler (POCIS). in Greenwood, R., Mills, G., Vrana, B., eds., Passive Sampling Techniques: Comprehensive Analytical Chemistry, Elsevier, v. 48, p. 171-197.

Alvarez D.A., Cranor W.L., Perkins S.D., Clark R.C., Smith S.B., in press, Chemical and toxicological assessment of organic contaminants in surface water using passive samplers: Journal of Environmental Quality.

Blazer, V.S., Iwanowicz, L.R., Iwanowicz, D.D., Smith, D.R., Young, J.A., Hedrick, J.D., Foster, S.W., Reeser, S.J., 2007, Intersex (testicular oocytes) in smallmouth bass from the Potomac River and selected nearby drainages: Journal of Aquatic Animal Health, v. 19, p. 242-253.

Cahill, J.D., Furlong, E.T., Burkhardt, M.R., Kolpin, D.W., Anderson, L.G., 2004, Determination of pharmaceutical compounds in surface- and ground-water samples by solidphase extraction and high-performance liquid chromatography/electrospray ionization mass spectrometry: Journal of Chromatography A, v. 1,041, p. 171-180.

Daughton, C.G., Ternes, T.A., 1999, Pharmaceuticals and personal care products in the environment: agents of subtle change?: Environmental Health Perspectives, v. 107, p. 907-944. 
Denny, J.S., Tapper, M.A., Schmieder, P.K., Hornung, M.W., Jensen, K.M., Ankley, G.T., Henry, T.R., 2005, Comparison of relative binding affinities of endocrine active compounds to fathead minnow and rainbow trout estrogen receptors: Environmental Toxicology and Chemistry, v. 24, p. 2,948-2,953.

Huckins, J.N., Petty, J.D., Booij, K., 2006, Monitors of organic chemicals in the environment-semipermeable membrane devices: Springer, N.Y., p. 1-218.

Jones-Lepp, T.L., Alvarez, D.A., Petty, J.D., Huckins, J.N., 2004, Polar organic chemical integrative sampling (POCIS) and LC-ES/ITMS for assessing selected prescription and illicit drugs in treated sewage effluent: Archives of Environmental Contamination and Toxicology, v. 47, p. 427-439.

Keith L.H., 1991, Environmental Sampling and Analysis: A Practical Guide: CRC, Boca Raton, Fla., p. 101-113.

Lebo, J.A., Almeida, F.V., Cranor, W.L., Petty, J.D., Huckins, J.N., Rastall, A.C., Alvarez, D.A., Mogensen, B.B., Johnson, B.T., 2004, Purification of triolein for use in semipermeable membrane devices (SPMDs): Chemosphere, v. 54, p. 1,217-1,224.

Nishihara, T., Nishikawa, J, Kanayama, T., Dakeyama, F., Saito, K., Imagawa, M., Takatori, S., Kitagawa, Y., Hori, S., Utsumi, H., 2000, Estrogenic activities of 517 chemicals by yeast two-hybrid assay: Journal of Health Science, v. 46, p. 282-298.

Petty, J.D., Orazio, C.E., Huckins, J.N., Gale, R.W., Lebo, J.A., Meadows, J.C., Echols, K.R., Cranor, W.L., 2000, Considerations involved with the use of semipermeable membrane devices for monitoring environmental contaminants: Journal of Chromatography A, v. 879, p. 83-95.
Petty, J.D., Huckins, J.N., Alvarez, D.A., Brumbaugh, W.G., Cranor, W.L., Gale, R.W., Rastall, A.C., Jones-Lepp, T.L., Leiker, T.J., Rostad, C.E., Furlong, E.T., 2004, A holistic passive integrative sampling approach for assessing the presence and potential impacts of waterborne environmental contaminants: Chemosphere, v. 54, p. 695-705.

Rastall, A.C., Neziri, A., Vukonvic, Z., Jung, C., Mijovic, S., Hollert, H., Nikcevic, S., Erdinger, L., 2004, The identification of readily bioavailable pollutants in Lake Shkodra/ Skadar using semipermeable membrane devices (SPMDs), bioassays and chemical analysis: Environmental Science and Pollution Research, v. 11, p. 240-253.

Routledge, E.J., Sheahan, D., Desbrow, C., Brighty, G.C., Waldock, M., Sumpter, J.P., 1998, Identification of estrogenic chemicals in STW effluent. 2. in vivo responses in trout and roach: Environmental Science and Technology, v. 32, p. 1,559-1,565.

Routledge, E.J., Sumpter, J. P., 1996, Estrogenic activity of surfactants and some of their degradation products assessed using a recombinant yeast screen: Environmental Toxicology and Chemistry, v. 15, p. 241-248.

RxList.com, accessed January 27, 2008, at http://www.rxlist. $\mathrm{com} /$.

Schultz, M.M. and Furlong, E.T., Trace analysis of antidepressant pharmaceuticals and their select degradates in aquatic matrixes by LC/ESI/MS/MS: Analytical Chemistry, accessed February 6, 2008, at http://pubs3.acs.org/acs/ journals/toc.page? incoden $=$ ancham\&indecade $=0 \&$ involum $e=0$ \&inissue $=0$. 
Tables 
Table 1. Estimated water concentrations of select polycyclic aromatic hydrocarbons (PAHs) measured by semipermeable membrane devices (SPMDs) in the North Fork of the Shenandoah River, Virginia.

[Repl, replicate number; pg/L, estimated water concentration of chemical expressed as picograms per liter; MDL, method detection limit; MQL, method quantitation limit]

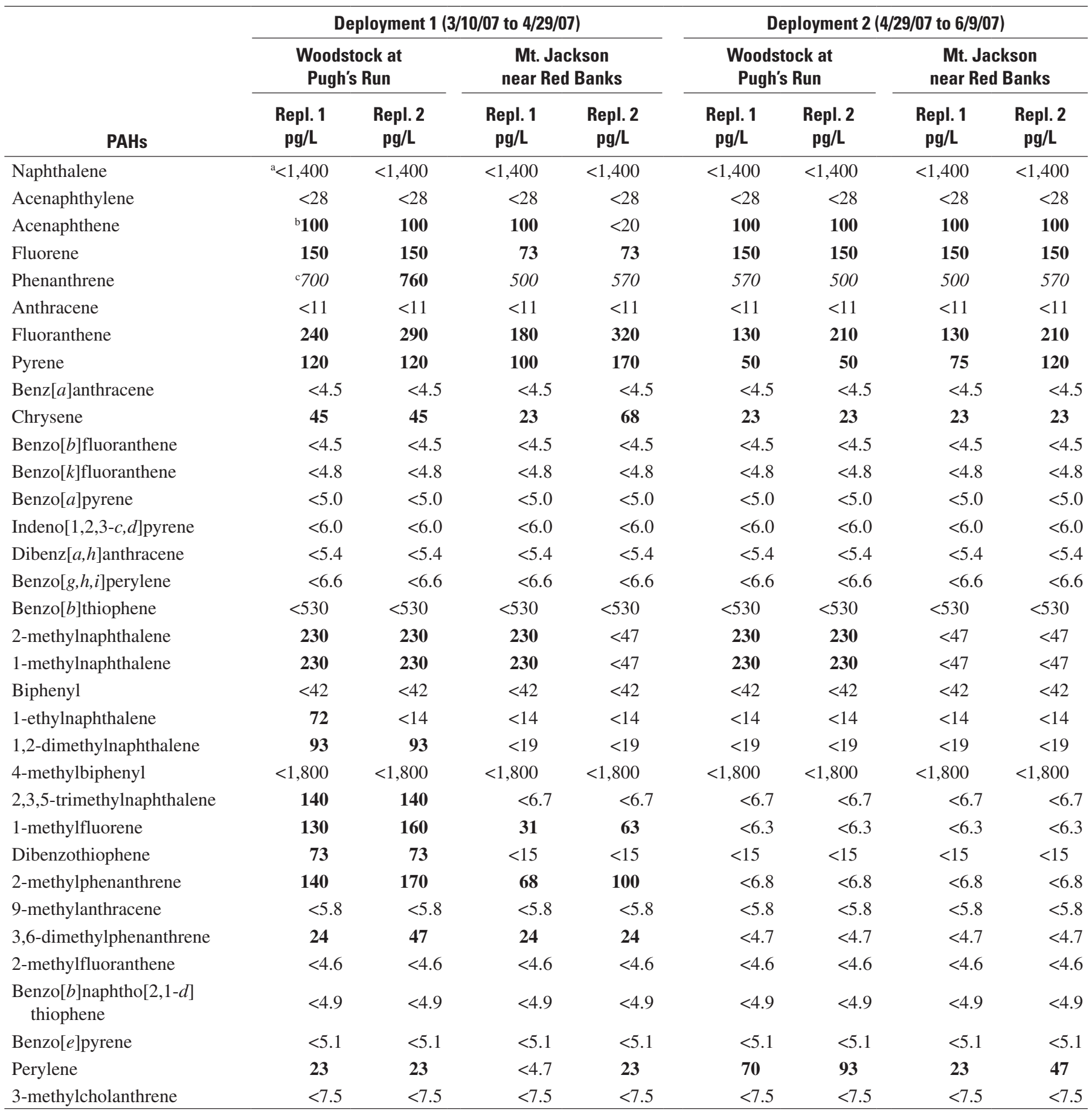

${ }^{a}$ Less than $(<)$ values are below the MDL.

${ }^{\mathrm{b}}$ Bold values are reportable values greater than the MQL.

${ }^{\mathrm{c}}$ Italic values are estimates greater than the MDL but less than the MQL and shown for informational purposes only. 
Table 2. Estimated water concentrations of select organochlorine pesticides and total polychlorinated biphenyls (PCBs) measured by semipermeable membrane devices (SPMDs) in the North Fork of the Shenandoah River, Virginia.

[Repl, replicate number; pg/L, estimated water concentration of chemical expressed as picograms per liter; MDL, method detection limit; MQL, method quantitation limit]

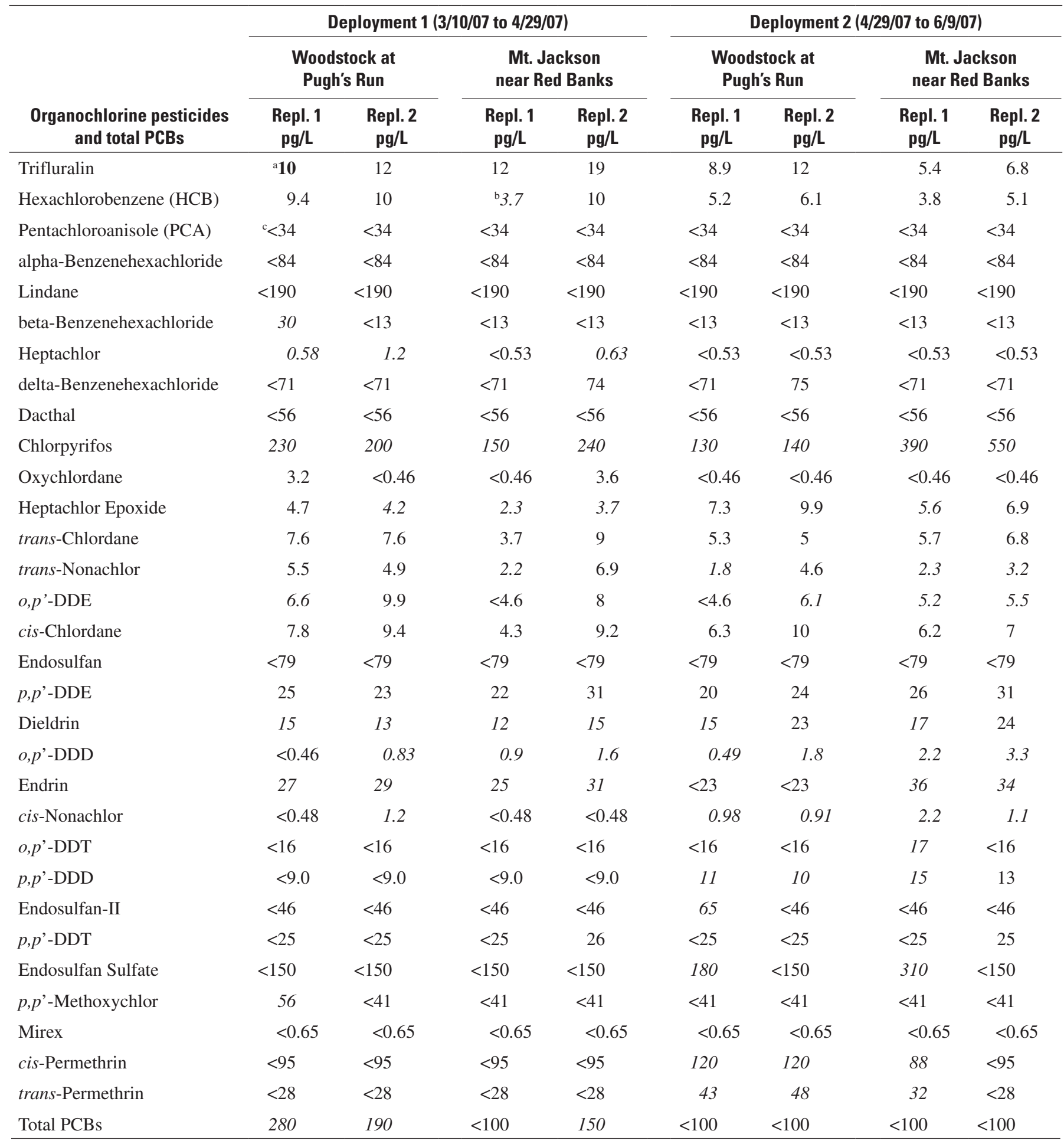

${ }^{\text {a }}$ Bold values are reportable values greater than the MQL.

${ }^{\mathrm{b}}$ Italic values are estimates greater than the MDL but less than the MQL and shown for informational purposes only.

${ }^{\mathrm{c}}$ Less than $(<)$ values are below the MDL. 
Table 4. Identification of select waste-indicator chemicals measured by polar organic chemical integrative samplers (POCIS) in the North Fork of the Shenandoah River, Virginia.

[Repl, replicate number; ng/POCIS, nanograms of chemical sampled by a single POCIS; MDL, method detection limit; MQL, method quantitation limit]

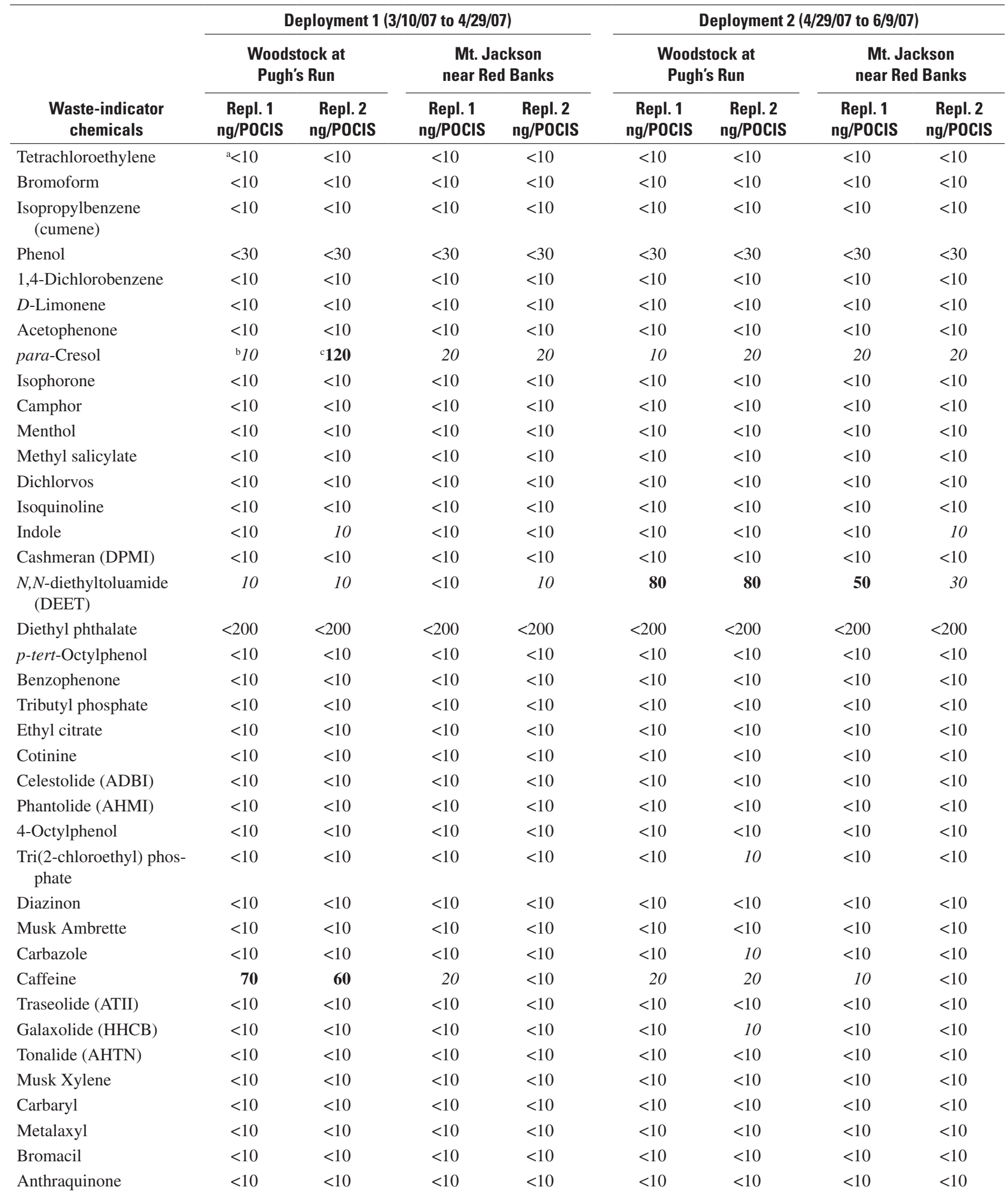


Table 4. Identification of select waste-indicator chemicals measured by polar organic chemical integrative samplers (POCIS) in the North Fork of the Shenandoah River, Virginia.-Continued

[Repl, replicate number; ng/POCIS, nanograms of chemical sampled by a single POCIS; MDL, method detection limit; MQL, method quantitation limit]

\begin{tabular}{|c|c|c|c|c|c|c|c|c|}
\hline \multirow{2}{*}{$\begin{array}{l}\text { Waste-indicator } \\
\text { chemicals }\end{array}$} & \multicolumn{4}{|c|}{ Deployment 1 (3/10/07 to 4/29/07) } & \multicolumn{4}{|c|}{ Deployment 2 (4/29/07 to $6 / 9 / 07)$} \\
\hline & \multicolumn{2}{|c|}{$\begin{array}{l}\text { Woodstock at } \\
\text { Pugh's Run }\end{array}$} & \multicolumn{2}{|c|}{$\begin{array}{c}\text { Mt. Jackson } \\
\text { near Red Banks }\end{array}$} & \multicolumn{2}{|c|}{$\begin{array}{l}\text { Woodstock at } \\
\text { Pugh's Run }\end{array}$} & \multicolumn{2}{|c|}{$\begin{array}{c}\text { Mt. Jackson } \\
\text { near Red Banks }\end{array}$} \\
\hline Musk Ketone & $<10$ & $<10$ & $<10$ & $<10$ & $<10$ & $<10$ & $<10$ & $<10$ \\
\hline $\begin{array}{l}\text { Tri(butoxyethyl) phos- } \\
\text { phate }\end{array}$ & $<10$ & $<10$ & $<10$ & $<10$ & $<10$ & $<10$ & $<10$ & $<10$ \\
\hline Triphenyl phosphate & $<10$ & $<10$ & $<10$ & $<10$ & $<10$ & $<10$ & $<10$ & $<10$ \\
\hline $\begin{array}{l}\text { Diethylhexylphthalate } \\
\text { (DEHP) }\end{array}$ & $<470$ & $<470$ & $<470$ & $<470$ & $<470$ & $<470$ & $<470$ & $<470$ \\
\hline
\end{tabular}

${ }^{a}$ Less than $(<)$ values are below the MDL.

${ }^{\mathrm{b}}$ Italic values are estimates greater than the MDL but less than the MQL and shown for informational purposes only.

${ }^{\mathrm{c}}$ Bold values are reportable values greater than the MQL. 
Table 5. Identification of select pharmaceuticals measured by polar organic chemical integrative samplers (POCIS) in the North Fork of the Shenandoah River, Virginia.

[Repl, replicate number; ng/POCIS, nanograms of chemical sampled by a single POCIS; ND, not detected; IDL, instrument detection limit; LOQ, limit of quantitation]

\begin{tabular}{|c|c|c|c|c|c|c|c|c|}
\hline \multirow{2}{*}{ Pharmaceuticals } & \multicolumn{4}{|c|}{ Deployment 1 (3/10/07 to 4/29/07) } & \multicolumn{4}{|c|}{ Deployment 2 (4/29/07 to $6 / 9 / 07)$} \\
\hline & \multicolumn{2}{|c|}{$\begin{array}{l}\text { Woodstock at } \\
\text { Pugh's Run }\end{array}$} & \multicolumn{2}{|c|}{$\begin{array}{c}\text { Mt. Jackson } \\
\text { near Red Banks }\end{array}$} & \multicolumn{2}{|c|}{$\begin{array}{l}\text { Woodstock at } \\
\text { Pugh's Run }\end{array}$} & \multicolumn{2}{|c|}{$\begin{array}{c}\text { Mt. Jackson } \\
\text { near Red Banks }\end{array}$} \\
\hline 1,7-dimethylxanthine & ${ }^{a}<5.0$ & $<5.0$ & $<5.0$ & $<5.0$ & $<5.0$ & $<5.0$ & $<5.0$ & $<5.0$ \\
\hline Albuterol & $<5.0$ & $<5.0$ & $<5.0$ & $<5.0$ & $<5.0$ & $<5.0$ & $<5.0$ & $<5.0$ \\
\hline Azithromycin & $<5.0$ & $<5.0$ & $<5.0$ & $<5.0$ & $<5.0$ & $<5.0$ & $<5.0$ & $<5.0$ \\
\hline Caffeine & b140 & 110 & $<5.0$ & $<5.0$ & 60 & $<5.0$ & $<5.0$ & $<5.0$ \\
\hline Carbamazepine & $<5.0$ & $<5.0$ & $<5.0$ & $<5.0$ & $<5.0$ & 0.65 & $<5.0$ & $<5.0$ \\
\hline Dehydronifedipine & $<5.0$ & $<5.0$ & $<5.0$ & $<5.0$ & $<5.0$ & $<5.0$ & $<5.0$ & $<5.0$ \\
\hline Diltiazem & $<5.0$ & $<5.0$ & $<5.0$ & $<5.0$ & $<5.0$ & $<5.0$ & $<5.0$ & $<5.0$ \\
\hline Diphenhydramine & $<5.0$ & $<5.0$ & $<5.0$ & $<5.0$ & $<5.0$ & $<5.0$ & $<5.0$ & $<5.0$ \\
\hline Erythromycin & $<5.0$ & $<5.0$ & $<5.0$ & $<5.0$ & $<5.0$ & $<5.0$ & $<5.0$ & $<5.0$ \\
\hline Miconazole & $<5.0$ & $<5.0$ & $<5.0$ & $<5.0$ & $<5.0$ & $<5.0$ & $<5.0$ & $<5.0$ \\
\hline Ranitidine & $<5.0$ & $<5.0$ & $<5.0$ & $<5.0$ & $<5.0$ & $<5.0$ & $<5.0$ & $<5.0$ \\
\hline Sulfamethoxazole & $<5.0$ & $<5.0$ & $<5.0$ & $<5.0$ & $<5.0$ & $<5.0$ & $<5.0$ & $<5.0$ \\
\hline Thiabendazole & $<5.0$ & $<5.0$ & $<5.0$ & $<5.0$ & $<5.0$ & $<5.0$ & $<5.0$ & $<5.0$ \\
\hline Fluvoxamine & $<0.9$ & $<0.9$ & $<0.9$ & $<0.9$ & $<0.9$ & $<0.9$ & $<0.9$ & $<0.9$ \\
\hline Norfluoxetine & $<0.9$ & $<0.9$ & $<0.9$ & $<0.9$ & $<0.9$ & $<0.9$ & $<0.9$ & $<0.9$ \\
\hline Norsertraline & $<0.9$ & $<0.9$ & $<0.9$ & $<0.9$ & $<0.9$ & $<0.9$ & $<0.9$ & $<0.9$ \\
\hline Paroxetine & $<0.9$ & $<0.9$ & $<0.9$ & $<0.9$ & $<0.9$ & $<0.9$ & $<0.9$ & $<0.9$ \\
\hline Paroxetine Metabolite & $<0.9$ & $<0.9$ & $<0.9$ & $<0.9$ & $<0.9$ & $<0.9$ & $<0.9$ & $<0.9$ \\
\hline Sertraline & $<0.9$ & $<0.9$ & $<0.9$ & $<0.9$ & $<0.9$ & $<0.9$ & $<0.9$ & $<0.9$ \\
\hline Venlafaxine & 2.8 & 1.2 & $<0.9$ & 1.7 & 5.9 & 10 & 2.3 & 6.2 \\
\hline
\end{tabular}

${ }^{\text {a }}$ For common-use pharmaceuticals, the lowest end of the calibration range, equivalent to $5 \mathrm{ng} / \mathrm{POCIS}$, was set at the IDL of the compounds with the least sensitivity in the analysis; a number of compounds had IDLs considerably lower.

b Bold values are reportable values greater than the IDL (common-use pharmaceuticals) or the LOQ (current-use antidepressants).

${ }^{c}$ For the current-use antidepressants, the LOQ is on the order of $0.9 \mathrm{ng} / \mathrm{POCIS}$, based on the LOQ reported in Schultz and Furlong (2008). 
Table 6. Estimated water concentrations of select hormones measured by polar organic chemical integrative sampler (POCIS) in the North Fork of the Shenandoah River, Virginia.

[Repl, replicate number; ng/L, estimated water concentration of chemical expressed as nanograms per liter; MDL, method detection limit; MQL, method quantitation limit]

\begin{tabular}{|c|c|c|c|c|c|c|c|c|}
\hline \multirow[b]{2}{*}{ Hormones } & \multicolumn{4}{|c|}{ Deployment 1 (3/10/07 to 4/29/07) } & \multicolumn{4}{|c|}{ Deployment 2 (4/29/07 to $6 / 9 / 07)$} \\
\hline & $\begin{array}{c}\text { Repl. } 1 \\
\text { ng/L }\end{array}$ & $\begin{array}{c}\text { Repl. } 2 \\
\text { ng/L }\end{array}$ & $\begin{array}{c}\text { Repl. } 1 \\
\text { ng/L }\end{array}$ & $\begin{array}{c}\text { Repl. } 2 \\
\text { ng/L }\end{array}$ & $\begin{array}{c}\text { Repl. } 1 \\
\text { ng/L }\end{array}$ & $\begin{array}{c}\text { Repl. } 2 \\
\text { ng/L }\end{array}$ & $\begin{array}{c}\text { Repl. } 1 \\
\text { ng/L }\end{array}$ & $\begin{array}{c}\text { Repl. } 2 \\
\text { ng/L }\end{array}$ \\
\hline 17及-Estradiol & ${ }^{\mathrm{a}}<1.3$ & $<1.3$ & $<1.3$ & $<1.3$ & $<1.6$ & $<1.6$ & $<1.6$ & $<1.6$ \\
\hline Estrone & $<0.66$ & $<0.66$ & $<0.66$ & $<0.66$ & $<0.79$ & $<0.79$ & $<0.79$ & $<0.79$ \\
\hline Estriol & $<0.66$ & $<0.66$ & $<0.66$ & $<0.66$ & $<0.79$ & $<0.79$ & $<0.79$ & $<0.79$ \\
\hline
\end{tabular}

${ }^{a}$ Less than $(<)$ values are below the MDL.

${ }^{\mathrm{b}}$ Italic values are estimates greater than the MDL but less than the MQL and shown for informational purposes only.

Table 7. Relative estrogenic potential of chemicals sampled by semipermeable membrane devices (SPMDs) and polar organic chemical integrative samplers (POCIS) deployed in the North Fork of the Shenandoah River, Virginia as determined by the Yeast Estrogen Screen (YES).

[Repl, replicate number; EEQ, estimated estradiol equivalents; ng E2/sample, estimated nanograms of 17ß-estradiol per sample which gives an equivalent response; NA, not applicable]

\begin{tabular}{|c|c|c|c|c|c|c|c|c|}
\hline & \multicolumn{4}{|c|}{ Deployment $1(3 / 10 / 07$ to $4 / 29 / 07)$} & \multicolumn{4}{|c|}{ Deployment 2 (4/29/07 to 6/9/07) } \\
\hline & \multicolumn{2}{|c|}{$\begin{array}{l}\text { Woodstock at } \\
\text { Pugh's Run }\end{array}$} & \multicolumn{2}{|c|}{$\begin{array}{c}\text { Mt. Jackson } \\
\text { near Red Banks }\end{array}$} & \multicolumn{2}{|c|}{$\begin{array}{l}\text { Woodstock at } \\
\text { Pugh's Run }\end{array}$} & \multicolumn{2}{|c|}{$\begin{array}{c}\text { Mt. Jackson } \\
\text { near Red Banks }\end{array}$} \\
\hline & $\begin{array}{c}\text { Repl. } 1 \\
\text { EEQ } \\
\text { ng E2/sample }\end{array}$ & $\begin{array}{c}\text { Repl. } 2 \\
\text { EEO } \\
\text { ng E2/sample }\end{array}$ & $\begin{array}{c}\text { Repl. } 1 \\
\text { EEO } \\
\text { ng E2/sample }\end{array}$ & $\begin{array}{c}\text { Repl. } 2 \\
\text { EEQ } \\
\text { ng E2/sample }\end{array}$ & $\begin{array}{c}\text { Repl. } 1 \\
\text { EEQ } \\
\text { ng E2/sample }\end{array}$ & $\begin{array}{c}\text { Repl. } 2 \\
\text { EE0 } \\
\text { ng E2/sample }\end{array}$ & $\begin{array}{c}\text { Repl. } 1 \\
\text { EE0 } \\
\text { ng E2/sample }\end{array}$ & $\begin{array}{c}\text { Repl. } 2 \\
\text { EEQ } \\
\text { ng E2/sample }\end{array}$ \\
\hline from SPMD & 1.8 & 2.1 & NAa & 1.7 & 0.7 & 0.6 & NA & 1.2 \\
\hline from POCIS & 55 & 22 & 14 & 55 & 21 & 79 & 61 & 55 \\
\hline
\end{tabular}

${ }^{a}$ Response was not greater than the 99 percent confidence interval of the negative controls.

Publishing support provided by:

Rolla Publishing Service Center

For more information concerning this publication, contact:

Director, USGS Columbia Environmental Research Center

4200 New Haven Road

Columbia, M0 65201

(573) 875-5399

Or visit the Columbia Environmental Research Center Web site at:

http://www.cerc.usgs.gov 

